Relations industrielles

Industrial Relations

\title{
Arbitration Statistics
}

Arbitration Boards in the Province of Quebec

Volume 6, numéro 2, mars 1951

URI : https://id.erudit.org/iderudit/1023242ar

DOI : https://doi.org/10.7202/1023242ar

Aller au sommaire du numéro

Éditeur(s)

Département des relations industrielles de l’Université Laval

\section{ISSN}

0034-379X (imprimé)

1703-8138 (numérique)

Découvrir la revue

Citer ce document

(1951). Arbitration Statistics: Arbitration Boards in the Province of Quebec. Relations industrielles / Industrial Relations, 6(2), 62-62.

https://doi.org/10.7202/1023242ar

Tous droits réservés @ Département des relations industrielles de l’Université Laval, 1951
Ce document est protégé par la loi sur le droit d'auteur. L’utilisation des services d'Érudit (y compris la reproduction) est assujettie à sa politique d'utilisation que vous pouvez consulter en ligne.

https://apropos.erudit.org/fr/usagers/politique-dutilisation/ 
planning and exercise of judgment, and, above all, the good feeling which comes from the knowledge that industrial relations work makes a most important contribution to personal, social, industrial and national welfare.

\section{ARBITRATION STATISTICS}

\section{Arbitration Boards in the Province of Quebec}

From January 1st, 1950 to December 31, 1950, 73 Arbitration Boards have been established by the Quebec Minister of Labour. On January lst, 1950, 22 boards were already in action. They had been formed in 1949. This brings the total of Arbitration Boards to 95 for 1950; the number of employees concerned is 29,036 . 80 , of the 95 . Boards, rendered their award during the year 1950 and 15 were still in function on January 1st, 1951.

The parties, by their respective arbitrator, have recommended voluntarily the President of the Board in $64.2 \%$ of the cases. One can certainly consider this fact as an expression of the desire of both parties to come to an agreement even when appealing to arbitration.

Of the 95 Arbitration Boards mentioned here, 87 were constituted for private enterprises, 4 for public services, and 4 for health services.

According to trade union affiliation, these Boards are divided as follows: CCCL, 34;
CCL (CIO), 20; TLC (AFL), 38; CLA Inc. 2 and Independent, 1 . The Industry Group distribution and employees concerned are the following: Manufacturing: 73 Boards covering 18,359 employees. Building Construction: 2 Boards for 3,800 employees. Transports and Communications: 7 Boards concerning 5,511 employees. Trade: 7 Boards for 745 employees. Services: 6 Boards and 621 employees.

As can be readily seen, the Manufacturing Group, covering the greatest number of workers has required the most boards of arbitration. It is also in this Group that, the main labour organizations count the greatest number of members in as much as the arbitration cases for 1950 are concerned .

It is interesting to note that 73 of these Boards concerning 18,359 employees have been formed for Manufacturing Industries, when only 22 covering 10,677 employees have been formed for the other groups.

\section{Clauses submitted to arbitration during the fiscal year $1949-50$}

From April 1, 1949, to April 1, 1950, the official statistics of the Department of Labour show that there had been 131 arbitration cases.

Here are the different clauses submitted to arbitration in these cases:

Jurisdiction 1; rights of management 2; after a strike 2; union security 42 ; grievance procedure 10; seniority clauses 16; promotion, lay-off 5; duration of labour 35; guaranteed minimum conditions 5; overtime 21; paid holidays 34 ; vacation with pay 46; statutory holidays 16 ; safety 5 ; social security 18 ; pension plans 5 ; apprenticeship 4 ; wages 91; job classification 11; duration and renewal of agreement 12; the whole collective agreement 30 .

It is easy to see that clauses dealing with wages are more numerous. Union security, vacation with pay, paid holidays, grievance procedure and the duration of labour are actually with salary provisions the main clauses brought to arbitration. 